\title{
Novel as a Cultural Narrative
}

\author{
Dr. Mohd Yousuf Khan ${ }^{1}$, Peer Salim Jahangeer ${ }^{2}$
}

\author{
${ }^{1}$ B.Ed. M.Phil (English), Ph.D., Awadhesh Pratap Singh University, Rewa, MP, India \\ ${ }^{2}$ M. Phil English, M.Ed, Ph.D (English), Research Scholar, Awadhesh Pratap Singh University, Rewa, MP, India
}

\begin{abstract}
Literature is a mosaic of multicultural actions and events reflected by it in a particular era of the history. It is the best vehicle to promote and preserve the cultural heritage from generation to generation. Novel is one of the best components through which the human thoughts and feelings have been transferred from ancestors to the offspring's. As behind every book that is written lies the personality of the man who wrote it, and as behind every national literature lies the cultural characters of the race which produced it, so behind the literature of any period lie the combined forces-personal and impersonal which made the life of that period. As a whole, cultural narration is only one of the channels of literature in which the energy of an age discharges itself in its political movements, religious thoughts, philosophical speculation, art; we have the same energy overflowing into other forms of expression. The study of cultural narration of a particular period of literary era will thus take us out into the wide field of history, by which we mean the history of politics and society, manners and customs, culture and learning, philosophy and religion.
\end{abstract} Keywords-Culture, Era, Heritage, Mosaic, Vehicle.

As there is a common racial character in the literary productions of any given people, so therefore there is a common time character in the literature productions of such people at any given period. A nation's life has its moods of exultation and depression, its epochs now of strong faith strenuous idealism, the dominant spirit of the hour, whatever that may be, will be directly or indirectly reveal itself in his work.. The cultural narration changes its modes of action, for example, to consider the various ways in which the large, permanent themes of literature love, hatred, jealousy, ambition, men's common joys and sorrows, the problems of life and destiny which were already old when literature began, and are as new as ever today - at taken up and handled, not merely by different great writers, but also by different peoples and at different times. The mark of changing temper can be easily observed in temper, tone, emphasis perspective, through its various forms of expression. The motive, say, of the love of man and women, from Greek tragedy to medieval romance, from the drama of the age of Shakespeare to that of the Restoration, from the prose fiction of the Eighteenth to that of the nineteenth century, from the English novel to that of contemporary France and discovering, moreover, that now one vehicle of expression and now another is for a time in the ascendant It endeavors us to trace the history of the transformation and alternation of the great literary forms-such as the lyric, the drama, the novel-under changing conditions and in response to shifting conceptions of literary art, as they are freshly shaped to ever-varying uses by the masters of different nations and of different periods. In one of the most familiar facts in the history of modern literatures we have an illustration of the profound influence exerted by the genius and the art of one race upon those of other races.

Literature is the totalized cultural narrative schema with action and events and encompassing the reflections of social norms of religion, race, caste, creed, fashion, music, rituals, and other related routines of a particular community during a period. Beginning from the Elizabethan era novel has vividly narrated the cultural aspects of society now and then .Elizabethan age which saw the flowing of poetry was a golden age of drama. In their portrayal of cultural panorama some of Shakespeare's plays represent hatred of the Jews, because Christians thought that Jews were responsible for killing of Jesus, the Christ. However, we see in Merchant of Venice deals with the relationship between Jews (Money lender Shylock) and the Christians. Merchant of Venice, treated shylock sympathetically and gave him some of the most beautiful speeches he ever wrote and Shylock imposed the condition of claiming a pound of flesh. The women in Shakespearian age are presented as possessions to be passed between fathers and husbands. In most cases, they are socially confined and unable to explore the world around them without chaperones.

Aphra Behn's (1640-89) Oroonoko (1688) is one of the first sustained studies of racial prejudice in western fiction. In the novel, the lovers, Oroonoko and Imoinda, both high-born black Africans, are taken as slaves to the English colony of Surinam in South American. Oroonoko leads a revolt of the slaves against their masters but later surrenders on promise of fair treatment by the colony's 
governor. Instead, he is betrayed, kills Imoinda to prevent her being sexually abused and is executed with extreme cruelty by the English colonists, for whom he had become a threat to, their way of existence - a potent symbol of the massive injustice and inhumanity of slavery as a system. Through 'Oroonoko', Behn establishes that there is no moral justification for one race enslaving another. As fiction for one race enslaving another. As Laura Brown has remarked: Oroonokomust be recognized as a seminal work in the tradition of antislavery writing from the time of its publication down to our own period...Historians of slavery have never neglected oroonoko ${ }^{1}$

Daniel Defoe's (1661-1731) Robinson Crusoe (1719) is structured on the pattern of spiritual autobiography, and the hero's own conversation experience, while stranded on an uninhabited desert island, effectively turns him in to a born-again Christian with the deeply personal relationship to God that is so characteristic of the evangelical ethos. In Jonathan Swift's(1667-1745)Gulliver's Travels (1726) the hero undertakes a series of voyages across the globe, to arrive by accident in lands completely unknown to Europeans, where cultural clashes are generally the norm. The Big-endians and little-endians in Lilliput, for example, are embroiled in a series of wars because of a minor difference in their eating habits. Yahooism represents the dark side of human nature that gives birth to unthinking prejudice against almost all others. Frances D. Louis has called this as 'anatomy of misunderstanding. ${ }^{2}$

Social class culture of Eighteenth century is portrayed in Samuel Richardson's (1689-1761) Pamela or, Virtue Rewarded (1740), the novel depicts the female dominance over the emotions of a man, and male dominance over the physicality of a woman. It also exposes the suppression o females by their male counterparts prevailing in the society.Henry Fielding's (1707-54) Joseph Andrews (1742) is a portrayal of importance of fashions of the era. The author through his protagonist Joseph examines the concept of class-system as a social menace, and finds that 'High People' and 'People of Fashion' no more in their characters than the rest of society.

Mary Wollstonecraft's (1757-97) Vindication of the Rights of Woman (1792) forms a protest against Burke's nostalgia for the age of Chivalry by ridiculing defunct upper class codes of behavior. But her treatise goes beyond a mere attack which keep the greater proportion of mankind in subservience. She argues "if woman be not prepared by education to become the companion of man, she will stop the progress of knowledge and virtue. Who made man the exclusive judge, Wollstonecraft demands if woman partake with him the gift of reason. She demanded woman education and eradication of gender bias which enslave womenkind. ${ }^{3}$

Jane Austen (1775-1817) works critique the novels of sensibility of the second half of the Eighteenth century and are part of the transition to Nineteenth century realism. She uses parody and burlesque for comic effect and to critique the portrayal of women in the eighteenth century. Austen highlights the dependence of woman on marriage to secure social standing and economic security, and brings to light the hardships women faced, who usually did not inherit money, could not work and where their only chance in life depended on the man they married. Austen's Pride and Prejudice (1813) opens with her ironic sentence of feminist morality as:

It is a truth universally acknowledged, that a single man in possession of a good fortune, must be in want of a wife. ${ }^{4}$

As we see Mrs. Bennet, a mother is seeking husbands for her daughter's in this novel. This indicates Austen's quest for woman empowerment. Jane Austen's novels reflect vividly the manner of conversation and language in eighteenth century, particularly of middle-class women as: Then observe Elizabeth, "You must comprehend a great deal in your idea of an ideal woman"... A woman must have a thorough knowledge of music, singing drawing, dancing and the modern languages to deserve the word; and besides this all she must possess a certain something of her air and manner of walking, the tone of her voice, her address and expressions, or the word will be but half - deserved"5

A Passage To India (1924-) is a novel by E.M. Forester (1879-1970) set against the backdrop of the British Raj and the Indian independence movement in the 1920. The novel is an intermingle cultural representation of Christianity, Islam and Hinduism. The story revolves around the characters: Dr. Aziz, his British friend Mr. Cyril fielding, Mrs. Moore, Miss Adela Quested, and occasional a Hindu Brahmin professor named Narayan Godbole. The narrative reveals Mrs. Moore's mystical characteristic of Multicultural assimilation Dr. Aziz's description of architecture of Mosques, temples, and churches, the importance of Malabar caves (representing syncretism, the echo that negates everything into Boum, provides unity a oneness), representation of cultural codes of these religious.

Toni Morrison's (1931)The Blue's Eye (1970) is a portrayal of incest, racism and child molestation. The story is about a year in the life of a young black girl named pecola who develops an inferiority complex due to her eye color (Blue) and skin (Black) the author presents a multitude of social condition in which the opinions of the 
people are warped by prejudice and unwritten social laws. Tony Morrison'sJazz (1992- ) introduces the new genre of Jazz music culture.Tony Morrison's Beloved (1987) is a multicultural novel resembling the different voices of Black slaves in a very ironical tone, in the form of a black narrative. Tony Morrison's concern lies in the multicultural aspects of black community. It represents the multiple voices of black slaves who were compelled to be displaced due to the brutal behavior of their white masters.

Cultural narration is a recurring theme in post war literature. In the Indian English novels different kinds of cultural narratives prevail, ranging from atrocities on minorities to cultural biases between the communities. Raja Rao (1908-2006) whose works are deeply rooted in Brahmanism and Hinduism. His The serpent and the Rope (1960), is a story of a search for spiritual truth in Europe and India. It established him as one of the finest Indian stylist" writing is my dharma" he once said. The theme of true marriage leading to self knowledge is the core of this novel. Man's life is barren and futile if he does not make incessant effort for the quest of the absolute. Dwelling on the importance of the Guru, Raja Rao observes in his novel:

The world is either unreal or real-the serpent or the rope, there is no between the two ... and looking at the rope from the serpent is to see paradise, saints, avatars, gods, hero'suniverses. For where so ever you go, you see only with the serpent's eyes...you see the serpent and in fear you feel you are it, the serpent, saint-one-the Guru-brings you lantern. The road is seen, the long white road. ${ }^{6}$

Raja Rao's Kanthapura (1938) is an archetype of India's Freedom movement. Rao's mythic design of Kanthapura is a unique portrayal of the freedom struggle. The novel, most artistically and realistically, captures the social and political milieu of India during the stirring days from 1919 to 1930. An outstanding aspect of RajaRao's narrative technique in Kanthapura is the use of religious metaphor. In the novel moorthy takes the help of Harikathaman Jayaramachar who intelligently mingles religion with politics when he talks to the unlettered villagers.

Whensoever, there is misery and ignorance, I come,..As he Jayaramchar, Hari Katha-man, he talks of Damayanthi and Shakuntala and Yashoda, he must say something about Swaraj. The subtlety of the Gandhian through and the complex political situation of pre-independence could be explained to the unlettered villagers only through legends and religious stories of gods. ${ }^{7}$

Keeping in the tradition of puranic style there are digressions now and then, but the rapidity of the action has its own rise and flow.Mulk Raj Anand's (1905) first novel untouchable (1935) has shown that none of the western theoretical models of attaining social justice, inducing the Rousseaitic, the Hegelian and the Marxist models is appropriate to theorizing the tragedy of Bakha's deterministic existence and the stubborn order that is responsible for the creation of the Bakha's of society. Anand through this novel sketches the caricature of the menace of untouchable in the Indian society during time the novel published.

In his Coolie (1936), Munno the protagonist also suffers the handcuffs of being a low caste Kshastriya boy. While Bakha's complicated existence as an untouchable is situated in the Varnashram of Hinduism, the 'hero-anti-hero' of Coolie Munoo's fate as a rickshaw puller is tied to his dehumanizing work as a coolie.

My novels were intended to be different from those of others, departures from the upper and middle section fictions". Wish to recreate" he adds, "the folk, whom I know intimately, from the lower depths, the lumpers and the suppressed, oppressed (and) repressed, those who have seldom appeared in our literature except in Sarat Chatterji, Prem Chand, Bibhuti, Tara Shankar and Maneck Bannerji (The Sources of protest). ${ }^{8}$

Rohinto on mistrys (1952) novels are concerned with the great inequities of the world; between the classes, genders, castes, and official hierarchies. Tormented souls and human beings with little social capability such as Gustad and Dinshaw (such a long journey), Om and Ishwar (A Fine Balance) and Nariman Vakeel (Family Matters) are all victims. Their fates are decided by the vagaries of relations within family class, caste, and community. Mistry's novels present a centrifugal movement of ever widening circles of these relationships. a, Om and Ishwar are the only surviving members of their family the rest were burnt to death by upper caste land lards for defying established conventions Mistry says :

I prefer to think that god is against quilt maker. With an infinite variety of designs. And the quilt has grown so big and confusing, the pattern is impossible to see, the squares and diamonds and triangle don't so well together any more, and it's all become meaningless. So he has abandoned it .

.Amitav Ghosh's (1956) all novels are particularly portraying the cultural narrative ranging from communal conflicts to global harmony. His In an Antique Land (1992) is the narration of cross-cultures of Hindu, Muslims and Jews. The narrator Amitab evaluates the roles and rituals of these religions. The story of Bomma implies the Buddhist goddess Boom bhabi. There is a long interaction about 
religions of Hindu and Muslims, between protagonist Amitab and Mustafa Abi Soleh the novel introduces Hindu cultural creed of Sati and worshiping the cow. It also reveals Muslims, creed of believed in life after death, visiting the grave yards etc. Ghosh's The Shadow Lines (1988) is a narration of Hindu and Muslim families and their integral cross-culture relations. In this novel the characters like Tha'mma Tridib, Khalil are essentially the specimens of cross cultural relationship. Their intercultural interactions make the novel a mirror of cultural conflation. His The Glass Palace (2000) reflects the cross-cultural narrations of Indian, Burmese and Chinese people. It is a cultural saga of Burmese Royal family. Queen suplayat, king thebaw, Indian Rajkumar and Chinese Saya John. All of the characters intermix to give the reflection of multicularism; The Hungry Tide (2004) is the narration of bad plight of the people living closer to the dreadful jungles. It narrates mysterious and enchanting sundarbans-with the mangroves and man-eating predators, fishesand dolphins, tempests and tides, myth, culture and history. Ghosh's Sea of Poppies (2008) depicts how small farmers and agricultural laborers in colonial India were forced by circumstances to be coolies and how they were cultural related to each other. His River of Smoke (2011) is the second part of Ibis trilogy narrates the fate of canton laborers and emphasizes on their cultural relation who call each other as "Jahaz Bhai" and Jahaz Behne. Ghosh's all novels tactfully narrate the culture, religion nationality, family networks and language in a view of cross-cultural conflation.

The Great Indian Novel (1989) by Shashi Tharoor (1956) goes back to the period of pre-independence era with the backdrop of Indian political movement. Actually aware of the colonial gaze reserved for a literary production. Tharoor gives parodical discourse named 'Parodia Sacra' present in the text of The Great Indian Novel. This novel is a mixed saga of Indian freedom movement and Mythology. The name 'Mahabharata' can be translated into English as "The Great India". Tharoor adopts these names of the text under discussion and names it as The Great Indian Novel. Tharoor portrays the metaphorical symbolism of the characters and their actions in the novel which resembles the name of the sacred text 'Mahabharata'. It also resembles the mythical characters by name and appearance. For example, Ganga Datta-Gandhiji, Dhratarashtra-Nehru, V.V.C.Raja Gopalachari, Gandhari, The Grim-Kamla Nehru, Pandu, The Pale-Subhash Bose, Mohammad Ali, Karna-Mohammad Ali Jinnah. Mohammad Rafi- Maula Abul Kalam Azad and likewise all the characters in the novel. ${ }^{11}$ Shashi Tharoor, by choosing the great epic 'The Mahabharata', makes an audacious attempt to make parody of the traditional customs and traditions of ancient Indian. From choosing of the sacred text to exploring the characters with a new postcolonial perspective, Tharoor shows his colossal force to transform the epic into a 'parodia sacrathrough a contemporary fiction re-telling the same. While Tharoor continues the legacy of parody by imitating great epics and sacred religious texts with a satire of the conformist, the normative, the ancient as well as contemporary society, thus simultaneously creating a vision of discourse that laughs at held notions. Henevertheless, sustains his own style of innovation and individuality as he negotiates both the past and the contemporary from a postcolonial postmodern perspective.

The Garden of solitude (2011) by Siddhartha Gigoo (1974) is a poignant narration of a Kashmiri Pandit family driven away from the valley in the wake of armed insurgency and political turmoil. The protagonist Sridar, a young pandit boy, is torn apart as he reluctantly leaves his home situated in the beautiful valley along with his family as novel depicts:

All I dream of now is a garden of solitude, when I get a morsel of rice in the morning and morsel of rice in the evening.

The heart wending narrative by Gigoo is a clear picture of the pains felt by the valley's people in general when they left their homes, side by side it depicts their cultural habit of eating rice two times a day:"Every Truck carried a home and helplessness". The narrative also describes the pathetic conditions of pandits in migration camps in who are longing for their Muslim brothers, Gigoo says:

The migrants all day long on a rock mound and discussed the affairs of their community. Days were spent sighing and talking about their plight and their sordid condition. Waiting kept them busy for many it was a lacerating wait...Every day I lead the life of a centipede I crawl. I lick. I hide. I sting. I wake up to the fumes of kerosene in the morning and sting of speeding ants, feedings ravenously on the sugar spilled on the floor of the tent.

The central idea of the narrative of the novel is their dedicated to Kashmiri Pandits migration and the pathetic life they are living in migrant camps away from their ancestral homes.

\section{REFERENCES}

[1] A.G.Khan. Canadian Literature And Indian Literature New Perspective.. New Delhi: Creative Books, 1995. Pp.111-112. 
[2] Alexander, blue. Homosexuality in Victorian and Elizabethan literature:

http://www.studymode.com/essays.may05, 2012.

[3] Andrew, Sanders.The short oxford history of English literature. LONDON: Clarendon press, 1994.p. 340.

[4] D.H., Lawrence. Lady Chatterley's Lover. Italy: Tipographia Giuntina 1928, Chap. 14.

[5] Jane, Austen. Pride and Prejudice. London: T. Egelton, white hall, 1813 p.1, 27

[6] K.D., Verma. The metaphors of untouchable and coolie in Mulk Raj Anand's Novels Untouchable and Coolie and His Sense of Social Justice. USA: University of Pittsburghat Johnslown, Asiatic, Vol. 2 No.1 June, 2008. P.34.

[7] Kaushal, Sharma.Raja Rao (A study of his themes and techniques).New Delhi: Sarup \& Sons. p. 14, 15,30

[8] Nidhi, Gupta.Major themes in Rohinto Mistry's Novels. PSDI Lapis Lazuli, An International Literary Journal / Vol. II/issue-1/spring 2012. http//www.pintersociety.com

[9] Punya Shree, Panda. The parody ofthe sacred: A study of the characters in the great Indian Novel by Shashi tharoor. International Journal of Business, Humanities and Technology. vol.1, No.2. September 2011.

[10] Siddhartha, Giggo.The Garden of Solitude. New Delhi: Rupa publications India Pvt. Ltd. p.1, 66, 97

[11]Sim, struarte.The Eighteenth century novel and contemporary social issue. Edinburgh: Edinburgh press Ltd. 2008. p. 10, 37 